\title{
Increasing PhD students' employability by focusing on the academic entrepreneurship. The analysis of the entrepreneurial competences
}

\author{
Sabina Hodzic*
}

doi: 10.18543/tjhe-3(2)-2016pp347-387

\begin{abstract}
The aim of the present study was to explore the perspective for entrepreneurship among $\mathrm{PhD}$ students coming from variety of disciplines. More precisely, to identify the most important entrepreneurial competences for succeeding in the entrepreneurial venture, to explore whether these competences are being developed during the $3^{\text {rd }}$ cycle studies, and to explore the entrepreneurial intentions of the future doctors. In order to choose the most important entrepreneurial competences, individual semi-structured interviews with ten entrepreneurs from different fields were conducted. In addition, the importance of each competence was evaluated in form of the questionnaire, by seventeen entrepreneurs. After the qualitative and quantitative analysis of the interviews and the questionnaire, 20 competences were selected as the most important entrepreneurial competences. These 20 competences were then evaluated by $50 \mathrm{PhD}$ students from different fields of study. They evaluated the importance of each entrepreneurial competence, the level of its development during their $\mathrm{PhD}$ studies, and indicated their entrepreneurial intentions after finishing the $\mathrm{PhD}$. The most important and the most developed competences are presented in the results. In addition, the results showed relatively high entrepreneurial intentions in case of not finding a job after the $\mathrm{PhD}$ and in general. These results imply the need for incorporating some sort of entrepreneurial training and the development of entrepreneurial competences adapted to each subject area during the $\mathrm{PhD}$ studies.
\end{abstract}

Keywords: entrepreneurial competences; PhD students; employability; academic entrepreneurship; entrepreneurial intentions.

* This work was carried out at Deusto International Tuning Academy (DITA) at the University of Deusto, Bilbao, Spain, and was financially supported by DITA Short-Term Visit Scholarship. The Author would like to thank the entrepreneurs from the Deusto Entrepreneurship Center, more precisely DeustoKabi incubator, for their time and collaboration. A special thanks to Maria Yarosh from Deusto International Tuning Academy (DITA), for her help in conducting this investigation.

Sabina Hodzic (sabina.hodzic@gmail.com), PhD in Psychology of Human Resources, is currently a post-doc research fellow at the University Paris Descartes (Laboratoire Adaptations Travail - Individu), France. Her research is centred on emotional intelligence, well-being, stress, employability and entrepreneurship. More details are provided at the end this article. 


\section{Introduction}

One of the emerging needs in the current socio-educational context is to increase students' and young graduates' employability and this has been a common research topic. Nevertheless, increasing PhD students' employability is not so common in the literature (nor in practice), and even less if the focus is entrepreneurship.

According to the Eurostat data ${ }^{1}$ there were an estimated 717,320 doctoral students in the EU-28 in 2012 (enrolled at ISCED level 6 - Second stage of tertiary education; leading to an advanced research qualification). The estimated number of those who finish the last stage of tertiary education in EU-28 in 2012 was more than 121 thousand people of which more than 31 thousand graduated in the fields of social and behavioral sciences and business. Unemployment rate for people with tertiary education (ISCED levels 5-8) in European Union (28 countries) in 2014 was $6.1 \%$. And although the tertiary education level unemployment rate is much lower than for people with lower educational levels, there is still almost 1.5 million highly educated unemployed people in Europe. Increasing people's (especially young people's) employability has been an important strategy goal of the European Council and European institutions ${ }^{2}$. However, increasing $\mathrm{PhD}$ students' employability has been mostly neglected, partly due to the common belief that PhD students will naturally continue their careers in the academia. Nonetheless, employment opportunities for young doctors are very limited, especially because of the big imbalance between the demand (for young researchers and/or professors) and supply (of young doctors). One of the less explored ways for addressing this issue and increasing students' employability is through enhancing their entrepreneurial competences and promoting entrepreneurship as a legitimate form of employment.

Therefore, the general aim of the present study is to explore the perspective for entrepreneurship among $\mathrm{PhD}$ students coming from variety of disciplines. More precisely, we were interested in detecting the most important entrepreneurial competences for engaging and succeeding in the entrepreneurial venture and see whether these competences are being developed during $3^{\text {rd }}$ cycle studies and in what way. Moreover, the study aims at exploring entrepreneurial intentions of $\mathrm{PhD}$ students and future doctors.

\footnotetext{
1 "Eurostat: Statistics Explained," European Commission, http://ec.europa.eu/eurostat/ statistics-explained/index.php/Main_Page.

2 "Eurostat: Statistics Explained," Europe-2020-strategy, http://ec.europa.eu/eurostat/ web/europe-2020-indicators/europe-2020-strategy
} 


\section{I.1. Entrepreneurship as a new form of employment for young doctors}

The main goal of doctoral programs is to "enable students to acquire research skills, competences and knowledge in a particular field of interest" ${ }^{3}$

According to European Union's European Qualifications Framework, ${ }^{4}$ third cycle (doctoral or specialization) degrees are awarded to students who:

- Have knowledge at the most advanced frontier of a field of work or study and at the interface between fields.

- Have the most advanced and specialized skills and techniques, including synthesis and evaluation, required solving critical problems in research and/or innovation and to extend and redefine existing knowledge or professional practice.

- Demonstrate substantial authority, innovation, autonomy, scholarly and professional integrity and sustained commitment to the development of new ideas or processes at the forefront of work or study contexts including research.

In other words, $3^{\text {rd }}$ cycle students should have competences which fit them for employment as professionals in their own (and related) fields or for a progression to a career in academic research.

However, as previously mentioned, not all of $\mathrm{PhD}$ students will find employment in academia and the mentioned competences (specific for their fields of studies) would probably not be sufficient to make them employable and ready to enter the global job market. As Wall and Welsch ${ }^{5}$ mention, skills gained through $\mathrm{PhD}$ studies need to be complemented with other, more generic, skills that would increase their employability and prepare them better for the labor market. One of the ways of increasing PhD students' employability prospects is through entrepreneurial competences.

Entrepreneurship has been the focus of research in many disciplines, from economy and management, to psychology and sociology and it

3 "Tuning-EuroPsy: Reference Points for the Design and Delivery of Degree Programmes in Psychology," http://www.deusto-publicaciones.es/deusto/index.php/es/tuning-es/tuningrefpoints-es.

4 "European Consortium for Accreditation, European Qualifications Framework", http:// ecahe.eu/w/index.php/European_Qualifications_Framework\#Level_8_is_compatible_with_ the_Framework_for_Qualifications_of_the_European_Higher_Education_Area.

${ }^{5}$ Glenda P. Wall and Carsten P. Welsch, "Employability in Europe: Enhancing Post Graduate Complementary Skills Training" (paper presented at HEA STEM Learning \& Teaching Conference, Birmingham, UK, April 17-18, 2013. 
managed to become a true cross-disciplinary concept. Different aspects of entrepreneurship, though, have received research attention from different disciplines. For instance, the entrepreneurial individual has been more a focus of psychological studies, while a so-called macro approach to entrepreneurship has been a subject of economic research.

Independent of the disciplinary approach to entrepreneurship, it has been identified as an important and valuable source of employment and reemployment. ${ }^{6,7}$ Entrepreneurship is defined as a specific interaction between individuals and their environment, consisting of having entrepreneurial intent and identifying, evaluating and exploiting opportunities. ${ }^{8,9,10}$

When it comes to academic entrepreneurship, in the present research we would like to adopt a broader view on what academic entrepreneurship represents and how it differs and resembles "standard" entrepreneurship. According to Franzoni and Lissoni ${ }^{11}$, academic entrepreneurs are outstanding scientists who are directed toward commercialization of their research findings (either via technology transfers, patents, university spin offs etc.) in order to broaden their influence or achieve financial resources for future research. The "results" or outcomes of entrepreneurship can be creating value ${ }^{12}$ or creating a company, ${ }^{13}$ or the individual can demonstrate entrepreneurial activities inside the organization. ${ }^{14}$ In this line, the outcomes of academic entrepreneurship can

${ }^{6}$ Robert Hisrich, Janice Langan-Fox, and Sharon Grant, "Entrepreneurship research and practice: A call to action for psychology," American Psychologist 62, $\mathrm{n}^{\circ} 6$ (2007): 575-589, doi: 10.1037/0003-066X.62.6.575.

${ }^{7}$ Nikolaj Malchow-Moller, Bertel Schjerning, and Anders Sorensen, "Entrepreneurship, job creation and wage growth," Small Business Economics 36 (2011): 15-32, doi: 10.1007/ s11187-009-9173-y.

${ }^{8}$ Scott Shane and Sankaran Venkatarama, "The promise of entrepreneurship as a field of research," Academy of Management Review 25 (2000): 217-226, doi: 10.1016/S01492063(03)00016-3.

9 Christopher L. Shook, Richard L. Priem, and Jeffrey E. McGee, "Venture creation and the enterprising individual: A review and synthesis," Journal of Management 29 (2003): 379399, doi: 10.1016/S0149-2063(03)00016-3

${ }_{10}$ Jonathan T. Eckhardt and Scott A. Shane, "Opportunities and entrepreneurship", Journal of Management 29 (2003): 333-349, doi: 10.1016/S0149-2063(02)00225-8.

${ }^{11}$ Chiara Franzoni and Francesco Lissoni, "Academic entrepreneurs: Critical issues and lessons for Europe," in Universities, knowledge transfer and regional development: geography, entrepreneurship and policy, ed. Attila Varga (Cheltenham, U.K. and Northampton, Mass.: Elgar, 2009), 163-190.

${ }_{12}$ Hisrich, Langan-Fox and Sharon Grant, "Entrepreneurship research,” 575-589.

13 Mariola Laguna, "Self-efficacy, self-esteem, and entrepreneurship among the unemployed," Journal of Applied Social Psychology 43, $\mathrm{n}^{\circ} 2$ (2013): 253-262, doi: 10.1111/j.1559-1816.2012.00994.x.

${ }^{14}$ Shane and Venkatarama, "The promise," 217-226. 
be expanded to identifying new research areas and sources of funds or identifying opportunities with commercial market applications, as well.

Nevertheless, the scope and influence of academic entrepreneurship to large extent depends on institutional, organizational and political factors. ${ }^{15}$ Some countries, such as USA have a longer tradition of fostering and regulating academic entrepreneurship and therefore more success in it. ${ }^{16}$ Therefore, it is not surprising that the research topics related to academic entrepreneurship usually focus on university spin-offs, technological transfer, policies and legislation, and more macro factors in general, offering little about the entrepreneurial individual and integration of scientific knowledge and skills and the commercial success.

In this context, Siegel and Wright ${ }^{17}$ in their review on academic entrepreneurship propose several new perspectives of research in order to understand better the different aspects of academic entrepreneurship. However, none of the perspectives and research questions reflect the need to study the entrepreneurial individual. In other words, how to equip academics for successful entrepreneurial career.

Some earlier studies regarding academic entrepreneurship have called for analysis of the nature and behavior of academic entrepreneurs. ${ }^{18}$

Researchers in the field of entrepreneurship have always tried to identify what distinguishes entrepreneurs from non-entrepreneurs. Independent of the entrepreneurial outcome, it is believed that entrepreneurial individuals differ in some aspects from people who do not share this entrepreneurial spirit or intention. In this sense, they have tried to detect the individual differences that are believed to affect the entrepreneurial process. Thus, some claim it is entrepreneurial self-efficacy (people's belief in their ability to take entrepreneurial actions based on their assessment of the necessary skills they possess), ${ }^{19,20,21}$

15 Franzoni and Lissoni, “Academic entrepreneurs,” 163-190.

16 Ibid.

17 Donald S. Siegel and Mike Wright, "Academic entrepreneurship: Time for a rethink?" British Journal of Management 26, $\mathrm{n}^{\circ} 4$ (2015): 582-595, doi: 10.1111/1467-8551.12116.

${ }_{18}$ Mike Wright, Sue Birley, and Simon Mosey, "Entrepreneurship and university technology transfer," Journal of Technology Transfer 29, $\mathrm{n}^{\circ}$ 3-4 (2004): 235-246, doi: 10.1023/B:JOTT.0000034121.02507.f3.

${ }^{19}$ Chao C. Chen, Patricia G. Greene and Ann Crick, "Does entrepreneurial self-efficacy distinguish entrepreneurs from managers?" Journal of Business Venturing 13 (1998): 295-316, doi: 10.1016/S0883-9026(97)00029-3.

${ }^{20}$ Alex F. De Noble, Dong Jung, and Sanford B. Ehrlich, "Entrepreneurial self-efficacy: The development of a measure and its relationship to entrepreneurial actions," in Frontiers of Entrepreneurship Research, ed. Paul D. Reynolds (Babson College, Babson Park, MA, 1999), 73-87.

${ }^{21}$ Laguna, "Self-efficacy," 253-262. 
some that it is entrepreneurial intention, and some argue that optimism, risk taking and tolerance of ambiguity are those key individual differences that distinguish entrepreneurs from non- entrepreneurs. ${ }^{22}$

Nevertheless, these mentioned psychological characteristics are not sufficient to explain what distinguishes entrepreneurs from non-entrepreneurs and entrepreneurs from successful entrepreneurs. As some authors suggest, personality traits and cognitive abilities are important but not sufficient determinants of successful entrepreneurship. ${ }^{23}$ Therefore, it is necessary to include other aspects in order to better explain the entrepreneurial process. One of these other aspects are entrepreneurial competences.

In the present study we would like to explore and identify entrepreneurial competences that are equally important for the entrepreneurial process as personality traits or cognitive abilities, by focusing on a specific population - PhD students.

\section{I.2. Previous examples of developing employability among students}

Although not a very common topic, increasing students' (and especially $\mathrm{PhD}$ students') employability has been a subject of few relevant studies that are described below. Wall and Welsch, ${ }^{24}$ for instance, focused on bridging the gap between the academia and the job market and helping $\mathrm{PhD}$ students enhance their employability prospects. They identified important general skills, unrelated to the specific field of study that could be taught during the PhD studies and thus help future doctors in their career development. These skills included time management, team work and networking, assertiveness, writing skills, career planning, to mention some of them. These skills were taught in a form of different workshops and the authors suggest that they be embedded in the research training across all universities in Europe.

Another relevant research focused on entrepreneurship development in higher education, more precisely, on the university-enterprise relationship in enhancing entrepreneurship among university students. The aim of this research was to investigate the way the main stakeholders-academics,

22 Shane and Venkatarama, "The promise," 217-226.

${ }^{23}$ Susana Santos Correia, António Caetano, and Luís Curral, "Psychosocial aspects of entrepreneurial potential," Journal of Small Business \& Entrepreneurship 26, $\mathrm{n}^{\circ} 6$ (2013): 661685, doi: 10.1080/08276331.2014.892313.

24 Wall and Welsch, "Employability in Europe." 
employers, students and graduates - view the training of entrepreneurial competences. ${ }^{25}$

The main objective of the project was to define generic ${ }^{26}$ entrepreneurial skills for the students and guidelines for professors in order to adjust the theoretical training to the requirements of the practical placement, in terms of entrepreneurship. To do so, key entrepreneurial competences were identified and the level of their importance for each stakeholder was compared.

One of the interesting findings of this study was the importance of several generic entrepreneurial competencies (or skills) that several stakeholders mentioned. The authors identified communication and presentation skills, creativity, teamwork etc. among the things that should be included in universities' curricula in order the students could adjust better to their practical placements and to improve the entrepreneurial training.

\section{I.3. The aims of the study}

In this sense, the aim of the present study is two-fold. First, the study tries to identify the most important entrepreneurial competences necessary for pursuing (academic) entrepreneurial activities. More precisely, to identify generic entrepreneurial competences that two important target groups $(\mathrm{PhD}$ students and young entrepreneurs) find important, relevant and necessary for potential entrepreneurial ventures. The term "entrepreneurial competences" will be used to refer to all those competences that are considered as necessary or highly instrumental for a person who wants to become an entrepreneur (a successful entrepreneur). Second, the aim is to examine to what degree and how are these entrepreneurial competences being developed during the doctoral studies and through doctoral programs.

The main research questions of the present study are:

- Which entrepreneurial competences are considered important for starting and succeeding in own bussiness/venture/project according to young entrepreneurs?

${ }^{25}$ Marcela Rodica Luca and Laura Teodora David, "Tuning research on universityenterprise partnership in training entrepreneurship" (European University-Enterprise Cooperation Network, Project EUE-NET), retrieved from http://www.eue-net.org/_download/ EUE-Net_Tuning_book.pdf.

${ }^{26}$ Generic competences refer to those multifunctional, transversal, mentally complex and multidimensional combinations of knowledge, abilities, attitudes, roles and responsibilities as developed in Aurelio Villa Sanchez and Manuel Poblete Ruiz, eds., Competence-based learning. A proposal for the assessment of generic competences (Bilbao: Deusto University Press, 2008). 
- Which entrepreneurial competences are considered important for starting and succeeding in own bussiness/venture/project according to PhD students?

- At what level and how are important entrepreneurial competences developed during doctoral studies?

-What are entrepreneurial intentions of the $\mathrm{PhD}$ students?

\section{Method}

\section{II.1. Literature review}

The initial pool of entrepreneurial competences was created after reviewing some of the most relevant publications about entrepreneurship and more precisely, about entrepreneurial competences. The aim was to identify some of the most important competences that different authors in the field highlighted as essential for successful entrepreneurship. As already mentioned, the term "entrepreneurial competences" is used to refer to all those competences that are considered as necessary and useful for a person who wants to become an entrepreneur (a successful entrepreneur). The summary of the used sources and different classifications of the competences is presented in Annex 1. After gathering the competences, a synthesis of all the gathered information was made and an initial list of 38 competences was created.

\section{II.2. Sample and procedure}

After creating the initial pool of 38 competences, a pilot interview was conducted with one entrepreneur in order to evaluate the importance of each competence and create the final list of entrepreneurial competences which would be assessed by other entrepreneurs. After analyzing the answers from the pilot interview, the following aspects were modified:

- We introduced a signed consent to be presented to and signed by all the interviewees, through which they would be informed about the objective of the study and the scientific purpose of all the obtained information. The informed consent is presented in Annex 2.

- Two additional questions were added to the initial interview structure:

- Is there something from your studies that helped you in particular to start your own business?

- What would you include to your study program that would help future entrepreneurs? 
- It was decided to include a list of definitions (a definition for each competence) in case the respondent does not understand fully some of the competences or would like to consult it.

Additionally, some aspects to be improved by the interviewer were analyzed and agreed to be considered for the following interviews:

To focus on identifying important factors for entrepreneurship that are more competence-related. For example, if the answers to questions, such as "What helped you start your own business?" do not actually reflect any competence, the interviewer would try to re-formulate the question to guide the interviewee to give a more competence-related answer.

After analyzing the pilot interview two competences were eliminated: Capacity to evaluate perspectives for new ideas because it was considered to be very similar to Opportunity evaluation and development and Industry skills because it was too wide. In addition, some of the competences were renamed or slightly changed to be more understandable and less ambiguous. In addition, the literature on entrepreneurial competences was consulted again in order to define some aspects that the pilot interviewee mentioned, and four more competences were added to the initial list - Understanding market dynamics in a particular field, Negotiation and deal making skills, Business ethics and Team work. Finally, the lists of 40 competences and 40 corresponding definitions were made. Leaning on the literature review, these 40 competences were divided into four parts - entrepreneurial competences, psychological competences, social competences and technical competences. The list of 40 competences in English is presented in Annex 3.

In order to assess the importance and relevance of selected entrepreneurial competences and to choose the most important ones, 10 individual semistructured interviews (approx. 20-30 minutes long) with 10 entrepreneurs from different fields were conducted. All of the entrepreneurs were recruited in Deusto Entrepreneurship Center, more precisely, in DeustoKabi incubator, the University of Deusto's first Technology Based Business Nursery $(\mathrm{TBBN})$. The interviewed entrepreneurs signed the informed consent and agreed that the interview could be recorded. The total duration of all ten interviews was around three and a half hours. Apart from obtaining demographic data and data related to entrepreneurs' start-ups, the interview served to obtain an evaluation of the importance of the presented competences. The interviewees were asked to evaluate the importance of each competence presented in the form of questionnaire. The final version of the interview with the competences questionnaire and the list of definitions are presented in Annex 4 and 5. 
Moreover, in order to obtain more data for a quantitative analysis (quantitative evaluation of the importance of the competences) 7 more entrepreneurs (recruited at the local employment fair) completed an on-line version of the same competences' questionnaire that was given to the interviewed participants. They did not go through the interview but they did have a chance to add or point out the most important competences from the list or some other characteristic they found important that were not on the list, in open questions at the end of the questionnaire. ${ }^{27}$

All of the entrepreneurs who participated in the study (both those interviewed and the additional seven) were founders or co-founders of the company/start-up and all of them had at least a university degree (except one interviewee who was finishing his university career). The majority were male (fourteen), and the age range was 21 to 43 years (mean age was 31.9 years). Almost all start-ups belong to Information and Communications Technology sector, but some of them offer services and some offer products. In addition, not all of the start-ups were in the same development phase - some of them were at the beginning (establishment or capital search) and some of them were more mature (product launch or growth). The average duration of the start-ups whose founders were interviewed is almost 2 years ( 23.9 months), the longest one having more than 4 years and the shortest one 3 months duration.

Table 1

Classification of educational areas of the entrepreneurs who participated in the study

\begin{tabular}{|l|c|}
\hline \multicolumn{1}{|c|}{ Education } & $\mathrm{N}^{\circ}$ \\
\hline IT Engineering & 8 \\
\hline Advertising & 3 \\
\hline Telecommunications engineering & 1 \\
\hline Electronic engineering & 1 \\
\hline Fine arts & 1 \\
\hline Law & 1 \\
\hline Journalism & 1 \\
\hline Superior technical education & 1 \\
\hline Total & 17 \\
\hline
\end{tabular}

27 The on-line version of the questionnaire consisted of the same list of 40 competences that was given to the interviewed participants. 
Table 2

Development phases of the start-ups that participated in the study

\begin{tabular}{|l|c|}
\hline \multicolumn{1}{|c|}{ Phase } & $\mathrm{N}^{\circ}$ \\
\hline Establishment & 2 \\
\hline Project design & 3 \\
\hline Capital search & 1 \\
\hline Growth & 8 \\
\hline Optimization & 1 \\
\hline Product launch/ product selling & 2 \\
\hline Total & 17 \\
\hline
\end{tabular}

\section{II.3. Interview}

The purpose of the interview was to evaluate the importance of different entrepreneurial competences according to entrepreneurs and to choose the most important to be included in the final questionnaire. The interview consisted of 3 parts. First part was dedicated to collecting some general demographic and professional data, such as age, sex and start-up type and duration. Along with that data, the participants were asked about the factors and characteristics they consider important or necessary for entrepreneurship. After that, they were given the list with 40 competences to evaluate their importance for entrepreneurship on a scale from 1 (Not important at all) to 5 (Very important). Finally, the last part served to fulfil the data from the questionnaire, asking the participants to add or point out any additional competence or characteristic they consider important for the entrepreneurial process.

\section{II.4. Analysis of the data obtained through the interviews with the entrepreneurs and the design of the questionnaire for doctoral students}

The data obtained from the interviews, as well as the scoring of the competences was analyzed in detail. After calculating the final score for each competence, the median score was calculated and it was decided that the competences that obtained a score higher than the median score (that is higher than 4.06) would be kept and included in the version of the questionnaire designed for the PhD students. 
The ranking of the importance of all entrepreneurial competences made by entrepreneurs is presented in Annex 6. As can be seen in Annex 6, several competences indicate very similar means (e.g. 4.47, 4.53), implying that the interviewed entrepreneurs considered these competences to be highly and equally important. However, the competence that had the highest score (in comparison with the other competences) was Orientation toward the clients (4.82). This competence was also mentioned as important by various interviewees during the interview. The entrepreneurs we interviewed think that knowing how to listen to the clients and their needs is a necessary condition to have success in the new business.

Besides client orientation, Market orientation (identifying, evaluating and developing market opportunities) was also considered as very important by entrepreneurs. When discussing about the reasons why they started their own business, besides other reasons, it became clear that recognizing the opportunity and evaluating it as something viable and valuable (and further exploiting that opportunity) was something that all of the interviewed entrepreneurs had experienced. In addition, it was decided to merge two competences into one - Market opportunity identification/recognition and Identification and definition of a viable market niche - and name it Identification of market opportunities or a viable market niche. The reason for this was that the meaning of these two competences was very similar and it reflected the same competence.

Moreover, after analyzing the answers from the individual interviews (the qualitative part) it was decided to add two more competences from the list that did not score above the median but were mentioned in various interviews as important. The first is Innovation, which, in one form or another, emerged as an important factor for entrepreneurship. Several interviewees mentioned that added value was extremely important for a successful business. People usually think if they don't invent a new nonexisting product they won't succeed in the business, but that is wrong according to the interviewed entrepreneurs. The second is Written and oral communication skills. Various interviewees mentioned that oral and written expression and public speaking was something they either learned during their careers that helped them or they think it should be included in the current study programs in order to help future entrepreneurs.

In addition to the above, more than half of the respondents emphasized the persistence and resilience (be able to dedicate a lot of time, sacrifice, not give up, not listen to bad comments, have good will etc.) as a highly important factor or even the key factor for entrepreneurship. This competence was supported by high scores on the questionnaire as well (4.53). 
According to the scoring, Technical competences were not found as important as anticipated, which was confirmed by the interviews as well several respondents mentioned that this is something that could be learned and that everyone can learn by themselves "on the way", if necessary. Some entrepreneurs would include technical and business skills and knowledge (budget, business plan, invoicing etc.) into study programs but they consider that most of those things are easily learned by oneself, and if a person is willing to learn and find information she would succeed in it. Thus, none of the technical competences were included in the final version of the questionnaire. Table 3 shows the highest (6) and the lowest (5) rated competences by the entrepreneurs.

Table 3

Highest and lowest rated entrepreneurial competences according to entrepreneurs' ratings

\begin{tabular}{|l|c|}
\hline \multicolumn{1}{|c|}{ Highest rated competences } & Mean \\
\hline $\begin{array}{l}\text { Customer orientation/ Capacity to understand customers' } \\
\text { needs }\end{array}$ & 4.82 \\
\hline Building trust & 4.60 \\
\hline Evaluation and development of market opportunities & 4.53 \\
\hline Decision making & 4.53 \\
\hline Understanding, analyzing and solving problems & 4.53 \\
\hline $\begin{array}{l}\text { Willingness to assert oneself/ Resilience/ Intense effort/ } \\
\text { Commitment / Endurance and adaptability }\end{array}$ & 4.53 \\
\hline & Mean \\
\hline IT competences rated competences & 3.53 \\
\hline Social perception & 3.41 \\
\hline Business plan preparation & 3.41 \\
\hline Financial and budgeting skills & 3.24 \\
\hline
\end{tabular}

In order to complete the quantitative analysis of the scores, we examined the semi-structured interviews looking for some additional factor or competence that was not included in our preliminary list that the entrepreneurs found important.

The synthesis of all the answers yielded some important factors, mostly psychological or social, thus none of these aspects were included in the final questionnaire. Nevertheless, we would like to mention these aspects: 
- The strongest reason for entering into entrepreneurial adventure for almost all the interviewees was a desire to be independent, to have autonomy in one's own work, not to depend on others. Although, other external factors might have contributed to entrepreneurship (lack of work, downsizing of the companies they previously worked in) they all mention this as their main motivation. This need for independence has been highlighted in previous research as well, as a primary motive that drives individuals to engage in the entrepreneurial process. ${ }^{28,29}$

- In addition to this, several interviewees mentioned passion, believing in your project/product/idea and believing in success as important. This aspect might reflect on what is often mentioned in entrepreneurial research and that is self-efficacy or entrepreneurial self-efficacy. People's belief in their ability to take entrepreneurial actions, having a good conception of themselves and high level of self-esteem are often considered a key determinant of entrepreneurial process or enterprising spirit. ${ }^{30,31,32}$ After talking to the entrepreneurs, this factor, along with the desire to be independent were marked as the primary motivational drives for the entrepreneurial process.

- Additional two factors that emerged as important were more socialrelated. Being around people in similar situation, such as other entrepreneurs, with the same problems/difficulties and doubts stood out as one of the helping factors. Sharing this experience helped the entrepreneurs feel more confident and secure about their own entrepreneurial adventure.

- Also, it was very clear that none of the interviewees would have gone into entrepreneurship without social support from their surroundings and, more importantly, without a partner(s). In addition, several interviewees mentioned that it is important to search for right and adequate partners that can complement their own knowledge and skills. This is also reflected in the analysis of the results from the questionnaire, where Network development (as we defined it) obtained a score higher than the median score and was included in the final version of the questionnaire.

${ }^{28}$ Caetano, Santos and Curral, "Psychosocial aspects," 661-685.

29 Shane Scott, Locke Edwin A, and Collins Christopher J., "Entrepreneurial motivation." Human Resources Management Review 13, n² (2003): 257-279. doi: 10.1016/S10534822(03)00017-2.

${ }^{30}$ De Noble, Jung, and Ehrlich, "Entrepreneurial self-efficacy," 73-87.

31 Santos, Caetano, and Curral, "Psychosocial aspects," 661-685.

32 Aurelio Villa Sanchez, and Manuel Poblete Ruiz, "Competence-based learning." 
The final list of competences included in the questionnaire for the doctoral students is presented in table 4 .

\section{Table 4}

Final list of competences included in the questionnaire for doctoral students

1. Have vision and share it with others

2. Identification of market opportunities or a viable market niche

3. Evaluation and development of market opportunities

4. Understanding market dynamics in a particular field

5. Development of products or services appropriate to the firms chosen market niche / product innovation

6. Negotiation and deal making skills

7. Customer orientation

8. Leadership capacity

9. Decision making

10. Understanding, analyzing and solving problems

11. Resilience / Endurance and Adaptability

12. Emotional stability / Emotional intelligence

13. Creativity

14. Innovation

15. Expresiveness

16. Written and oral communications skills

17. Network development

18. Interpersonal skills

19. Building trust

20. Team work

\section{II.5. Pilot subject feedback}

The first version of the questionnaire for doctoral students consisted of 3 parts as well. The first part was dedicated to assess the level of development of each competence during the doctoral studies. The second part was designed to evaluate the importance of the each competence for entrepreneurship. Finally, the last part included the questions about students' plans after they finish their studies and their intention to engage into entrepreneurship. This version of the questionnaire was completed by first pilot respondent. After the feedback from the pilot respondent, some 
competences were better defined and the questions about the students' plans were structured better. Also, the instructions were re-formulated to be more clear and understandable. The necessary time for completing the questionnaire was around 30 minutes according to the respondent.

After re-evaluating the purpose of the questionnaire, it was decided to change the part about evaluating importance of each competence, because it was expected that the majority of the competences would be ranked as very important, which would not yield interesting information for the study. Thus, this part was changed in a way that the respondents were asked to choose ten most important competences for entrepreneurship.

This new version of the questionnaire was sent to another pilot respondent and after his feedback, some small changes were made to the format. We then proceeded to collect data.

The final version of the questionnaire included 3 parts:

1. The students were asked to imagine that they will start their own business related to their $\mathrm{PhD}$ studies after they finish. They were the asked to assess each competence from the list of 20 competences according to the level of development during their $\mathrm{PhD}$ studies on scale 1 (not developed) to 4 (very developed). Evidence for the development of each competence was also asked for.

2. Students were asked to evaluate the importance of entrepreneurial competences by choosing ten most important competences for starting own business among the list of twenty competences.

3. Students were asked to report their entrepreneurial intentions after finishing $\mathrm{PhD}$, in general and if they do not find job after the $\mathrm{PhD}$.

\section{RESULTS}

\section{III.1. Quantitative results}

Some descriptive results regarding the age, sex and year of the $\mathrm{PhD}$ of the participants are presented in the following tables.

In addition, frequency and percentage of entrepreneurial intentions after finishing the $\mathrm{PhD}$ are presented in table 8 . Just under $40 \%$ of the candidates believed they might proceed to engage in entrepreneurial activity immediately after finishing their $\mathrm{PhD}$, but almost two thirds intended to do so in the longer term (or straight away in the event of not finding a job). No significant 
differences in entrepreneurial intentions (none of the three) were found according to the sex or year of study of the students.

Table 5

\begin{tabular}{|l|c|}
\multicolumn{2}{|c}{ Age } \\
\hline N & 50 \\
\hline Mean & 39.94 \\
\hline SD & 7.74 \\
\hline Minimum & 23 \\
\hline Maximum & 57 \\
\hline
\end{tabular}

Table 6

Sex

\begin{tabular}{|l|c|c|}
\hline \multicolumn{1}{|c|}{ Sex } & N & $\%$ \\
\hline Female & 27 & 54 \\
\hline Male & 23 & 46 \\
\hline Total & 50 & 100 \\
\hline
\end{tabular}

Table 7

Students according to the PhD year

\begin{tabular}{|l|c|c|}
\hline \multicolumn{1}{|c|}{ PhD year } & N & $\%$ \\
\hline 1 & 19 & 38 \\
\hline 2 & 15 & 30 \\
\hline 3 & 1 & 2 \\
\hline 4 & 5 & 10 \\
\hline 5 & 1 & 2 \\
\hline “Last year" & 3 & 6 \\
\hline Finished & 6 & 12 \\
\hline Total & 50 & 100 \\
\hline
\end{tabular}


Table 8

Students' entrepreneurial intentions

\begin{tabular}{|l|c|c|}
\hline \multicolumn{1}{|c|}{$\begin{array}{c}\text { Entrepreneurial intention after } \\
\text { finishing PhD }\end{array}$} & N & $\%$ \\
\hline Yes & 19 & 38 \\
\hline No & 18 & 36 \\
\hline I don't know & 50 & 26 \\
\hline Total & $\mathrm{N}$ & 100 \\
\hline Entrepreneurial intention in general & 33 & $\%$ \\
\hline Yes & 7 & 66 \\
\hline No & 10 & 14 \\
\hline I don't know & 50 & 20 \\
\hline Total & $\mathrm{N}$ & 100 \\
\hline Entrepreneurial intention in case of \\
not finding a job after the PhD
\end{tabular}

As for the development and importance of different entrepreneurial competences, the results can be seen in table 9. The results show that students rated Written and oral communications skills (rank 1) as the most developed competence during their $\mathrm{PhD}$ studies, followed by Understanding, analyzing and solving problems (rank 2), Creativity (rank 3), Team work (rank 4) and Resiliencel Endurance and adaptability (rank 5). The least developed competence during the $\mathrm{PhD}$ studies was found to be Evaluation and development of market opportunities (rank 20). Among the ten least developed competences the students identified were almost all the competences that were nominated "entrepreneurial competences" in the first version of the competences list (Recognition and identification of market opportunities or a viable market niche, Understanding market dynamics in a particular field, Development of products or services appropriate to the firms chosen market niche / product innovation). Also, three social competences (Expressiveness, Network development and Building trust) and two emotional 
competences (Emotional intelligence and Innovation) were rated as not so developed during the PhD studies.

As for the importance of different entrepreneurial competences, students rated Team work (rank 1) as the most important competence for entrepreneurship, followed by Network development (rank 2), Creativity (rank 2) and Recognition and identification of market opportunities or a viable market niche (rank 2). The least important competence, according to the students' rating, is Expressiveness (Rank 13), followed by Emotional intelligence (rank 12), Negotiation and deal making skills (rank 11) and Customer orientation (rank 10).

In addition, figure 1 shows a graphical representation of the development and importance of each entrepreneurial competences perceived by the $\mathrm{PhD}$ students. The scores of each aspect (development and importance) have been standardized to allow a visual comparison between the two aspects.

\section{Table 9}

The ranking of the importance and development of entrepreneurial competences made by students - in order of item list

\begin{tabular}{|l|c|c|c|c|}
\hline \multicolumn{1}{|c|}{ Competence } & $\begin{array}{c}\text { Rank } \\
\text { importance }\end{array}$ & Importance & $\begin{array}{c}\text { Rank } \\
\text { (development) }\end{array}$ & $\begin{array}{c}\text { Total points } \\
\text { (development) }\end{array}$ \\
\hline $\begin{array}{l}\text { 1. Have vision and share it with } \\
\text { others }\end{array}$ & 6 & 26 & 8 & 112 \\
\hline $\begin{array}{l}\text { 2. Recognition and identification } \\
\frac{\text { of market opportunities or a }}{\text { viable market niche }}\end{array}$ & $\underline{2}$ & 33 & 18 & 90 \\
\hline $\begin{array}{l}\text { 3. Evaluation and development } \\
\text { of market opportunities }\end{array}$ & 6 & 26 & 20 & 74 \\
\hline $\begin{array}{l}\text { 4. Understanding market } \\
\text { dynamics in a particular field }\end{array}$ & 8 & 23 & 19 & 83 \\
\hline $\begin{array}{l}\text { 5. Development of products or } \\
\frac{\text { services appropriate to the }}{\text { firms chosen market niche / }} \\
\text { product innovation }\end{array}$ & $\underline{5}$ & 28 & 16 & 94 \\
\hline $\begin{array}{l}\text { 6. Negotiation and deal making } \\
\text { skills }\end{array}$ & 11 & 19 & 15 & 95 \\
\hline 7. Customer orientation & 10 & 20 & 13 & 100 \\
\hline 8. Leadership capacity & 6 & 26 & 9 & 111 \\
\hline 9. Decision making & $\underline{3}$ & 30 & 6 & 123 \\
\hline
\end{tabular}




\begin{tabular}{|c|c|c|c|c|}
\hline Competence & $\begin{array}{c}\text { Rank } \\
\text { importance }\end{array}$ & Importance & $\begin{array}{c}\text { Rank } \\
\text { (development) }\end{array}$ & $\begin{array}{l}\text { Total points } \\
\text { (development) }\end{array}$ \\
\hline $\begin{array}{l}\text { 10. Understanding, analyzing and } \\
\text { solving problems }\end{array}$ & 7 & 24 & 2 & 135 \\
\hline $\begin{array}{l}\text { 11. Resilience/ Endurance and } \\
\text { adaptability }\end{array}$ & 5 & 28 & 5 & 125 \\
\hline $\begin{array}{l}\text { 12. Emotional stability / Emotional } \\
\text { intelligence }\end{array}$ & 12 & 12 & 11 & 105 \\
\hline 13. Creativity & $\underline{2}$ & 33 & 3 & 128 \\
\hline 14. Innovation & $\underline{4}$ & 29 & 14 & 100 \\
\hline 15. Expressiveness & 13 & 6 & 10 & 111 \\
\hline $\begin{array}{l}\text { 16. Written and oral } \\
\text { communications skills }\end{array}$ & 9 & 21 & 1 & 144 \\
\hline 17. Network development & $\underline{2}$ & 33 & 12 & 103 \\
\hline 18. Interpersonal skills & 8 & 23 & 7 & 123 \\
\hline 19. Building trust & 9 & 21 & 17 & 94 \\
\hline 20. Team work & 1 & 36 & 4 & 127 \\
\hline
\end{tabular}

Note. The most important competences are underlined and the highest developed are bolded.

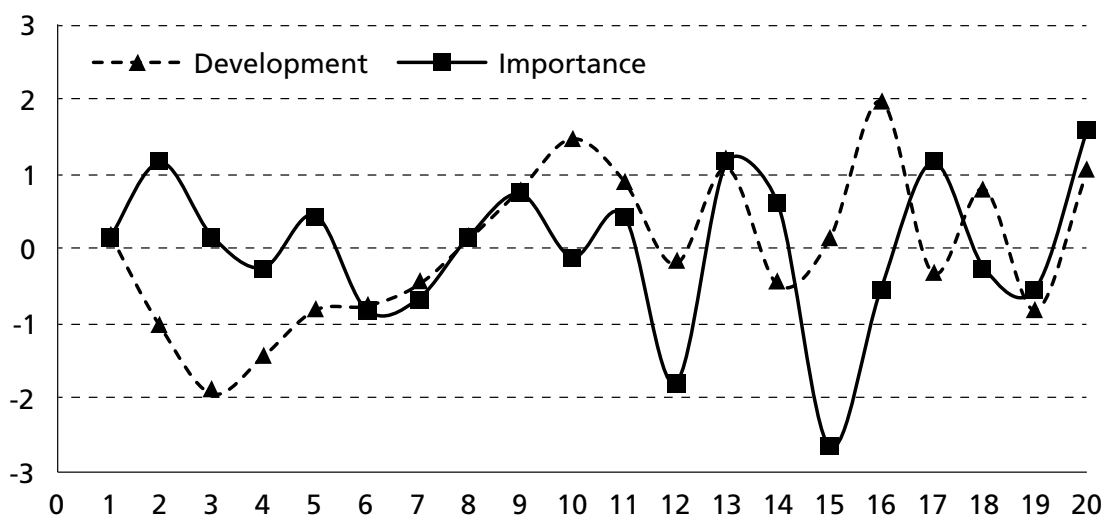

Figure 1

Diagram showing the development and importance of each competence according to students' answers

Note. The scores of each competence importance and development were standardized 


\section{III.2. Qualitative results}

In addition to the quantitative results obtained through the questionnaire (quantitative evaluation of the level of development and importance of the 20 entrepreneurial competences) we analyzed students' answers to the open questions and their thoughts on how the competences are developed during their PhD studies. Some of the most important aspects of this analysis are presented below.

Written and oral communications skills were ranked as the most developed competence during the $\mathrm{PhD}$ studies. The majority of the students mention shared experience, sessions with other students and with the professors, where sharing of the ideas and feedback is possible, following trends and market needs in the area.

Understanding, analysing and solving problems was identified as the essence of the $\mathrm{PhD}$ thesis and the $\mathrm{PhD}$ training. Different phases of the $\mathrm{PhD}$ process are identified as the context where this competence is developed.

Team work is identified as the most important entrepreneurial competence and among the most developed. Students mention that it is mostly developed through participation in joint projects and collaborating with their peers and other researchers. However, this competence reflects largely the type of $\mathrm{PhD}$ program or the culture that a particular $\mathrm{PhD}$ program promotes - whether they require team work and whether team work is something that is highlighted through participation in projects etc.

One of the least developed competences, and ranked as highly important for entrepreneurship (rank 2) was Recognition and identification of market opportunities or a viable market niche. This competence, if perceived as developed, was mainly dependent on field of study. More precisely, it was developed through particular subject during the PhD studies or specific task required from the $\mathrm{PhD}$ program.

Apart from the competences presented to the students in the questionnaire, other important aspects were mentioned as important for entrepreneurship. In first place, financial resources, economic viability and how to obtain and manage those was mentioned as an important factor to succeed in the entrepreneurial adventure. Many respondents mentioned this aspect as crucial for succeeding in the entrepreneurial venture. In addition, financial support, business plan and learning how to make a viability commercial plan was also highlighted as an important factor. Finally, although the so called psychological competences were not rated as very important according to the quantitative analysis, several aspects that fit this category were mentioned in the open question part of the questionnaire. Those aspects are assertiveness, 
persistence, ambition and confidence. These factors might be categorized as certain personality facets or psychological strengths that are viewed as important and helpful for the success in the entrepreneurial venture.

\section{Conclusion}

The focus of the present study was the employability prospects of $\mathrm{PhD}$ students and future doctors. Current job market and educational contexts are not in favour of the massive "production" of doctors in various fields of research. Increasing their employability prospects is of great importance, and should be considered as an alarming issue by all stakeholders - industry, educational institutions and professors, and students. Some isolated attempts to vouch for increasing post graduates' employability have been made. In general, the situation in UK is more favourable for post-graduates' employability prospects, because inclusion of different generic skills trainings has been made in various UK universities in one form or another. ${ }^{33,34}$ There is also an interesting initiative for promoting entrepreneurship among postgraduate students in Ireland. ${ }^{35}$ However, this trend is not common in the European universities. ${ }^{33}$

One of way to enhance $\mathrm{PhD}$ students' employability is by promoting entrepreneurship. Therefore, the aims of this study were to identify the most important entrepreneurial competences for succeeding in the entrepreneurial venture, to evaluate the extent to which these competences are developed among the $\mathrm{PhD}$ students of various areas, and to explore $\mathrm{PhD}$ students' entrepreneurial intentions.

Our results show that some competences that could be defined as entrepreneurial competences are being developed during the $\mathrm{PhD}$ studies, but many of them are not. In addition, the respondents to our study had, in general, relatively high entrepreneurial intentions, especially in the case of not finding a job after the PhD. These results imply the need for incorporating some sort of entrepreneurial training and the development of entrepreneurial competences adapted to each subject area. Moreover, students rated market-related competences (e.g. Recognition and identification of market opportunities or a viable market niche, Evaluation and development of market opportunities, Understanding market dynamics

33 Villa Sanchez, and Poblete Ruiz, "Competence-based learning."

${ }^{34}$ Wall and Welsch, "Employability in Europe."

35 http://www.tcd.ie/innovation/education/innovation-academy/. 
in a particular field or Development of products or services appropriate to the firms chosen market niche) as the least developed ones. This area could be one of the key focuses of future attempts to foster entrepreneurial competences among PhD students. However, as Meyer ${ }^{36}$ suggests, business plan oriented curricula is not the key and it neglects the entrepreneur in entrepreneurship. It is necessary to further explore the entrepreneurial individual and adapt the training to fit the description of a successful entrepreneur.

We do not wish to define academic entrepreneurship narrowly. Franzoni and Lissoni ${ }^{37}$ define academic entrepreneurs as scientists who are directed toward commercialization of their research findings. In the current academic entrepreneurship literature, this commercialization usually refers to technology transfers, patents, university spin offs etc. We believe that other outcomes of successful academic entrepreneurship should also be included. These outcomes might be identifying new research lines, funds and financial sources, possible university-company collaborations and different opportunities that can bring commercial application of the research findings and even recruit people who can bring these commercial benefits to the organization, research institution or the individual.

As for possible directions for future practical implication of the obtained findings, we argue for the incorporation of entrepreneurial competences training in the PhD curricula. Similar to Wall and Welsch' ${ }^{38}$ suggestions to include different general skills workshops in the PhD trainings for various research areas, we believe that entrepreneurial competences could be part of these generic skills, and that it is essential for increasing PhD students' employability prospects. In light of the definition of generic competences by Villa Sánchez and Poblete Ruiz, ${ }^{39}$ we propose that entrepreneurial competences should be considered as generic competences and are included in the $\mathrm{PhD}$ trainings in European universities.

In summary, universities and other relevant stakeholders in education, need to be aware of the limited employment options of their PhD students and should act in order to prevent possible problems in the career pursuit of their students. Future research on this topic, should investigate the best way to include these competences in the form and the content of $\mathrm{PhD}$ curricula, and make proposal for a suitably revised training framework.

${ }^{36}$ G. Dale Meyer, “The Reinvention of Academic Entrepreneurship,” Journal of Small Business Management, 49(1) (2011): 1-8, doi: 10.1111/j.1540-627X.2010.00311.x.

${ }^{37}$ Franzoni and Lissoni, “Academic entrepreneurs," 163-190.

38 Wall and Welsch, "Employability in Europe."

39 Villa Sanchez, and Poblete Ruiz, "Competence-based learning." 


\section{Bibliography}

Chen Chao C, Greene Patricia G, and Crick Ann. "Does entrepreneurial self-efficacy distinguish entrepreneurs from managers?" Journal of Business Venturing 13 (1998): 295-316. doi: 10.1016/S0883-9026(97)00029-3.

De Noble Alex F, Jung Dong, and Ehrlich Sanford B, "Entrepreneurial self-efficacy: The development of a measure and its relationship to entrepreneurial actions." In Frontiers of Entrepreneurship Research, edited by Paul D. Reynolds, 73-87. Babson College, Babson Park, MA, 1999.

Eckhardt Jonathan T, and Shane Scott A. "Opportunities and entrepreneurship." Journal of Management 29 (2003): 333-349. doi: 10.1016/S0149-2063(02)00225-8.

Franzoni Chiara, and Lissoni Francesco. "Academic entrepreneurs: Critical issues and lessons for Europe." In Universities, knowledge transfer and regional development: geography, entrepreneurship and policy, edited by Attila Varga, 163-190. Cheltenham, U.K. and Northampton, Mass.: Elgar, 2009.

Hisrich Robert, Langan-Fox Janice, and Grant Sharon. "Entrepreneurship research and practice: A call to action for psychology." American Psychologist 62, $\mathrm{n}^{\circ} 6$ (2007): 575-589. doi: 10.1037/0003-066X.62.6.575.

Laguna Mariola. "Self-efficacy, self-esteem, and entrepreneurship among the unemployed." Journal of Applied Social Psychology 43, $\mathrm{n}^{\circ} 2$ (2013): 253-262. doi: 10.1111/j.1559-1816.2012.00994.x.

Luca Marcela Rodica, and David Laura Teodora. "Tuning research on universityenterprise partnership in training entrepreneurship." European UniversityEnterprise Cooperation Network, Project EUE-NET. Retrieved from http:// www.eue-net.org/_download/EUE-Net_Tuning_book.pdf.

Malchow-Moller Nikolaj, Schjerning Bertel, and Sorensen Anders. "Entrepreneurship, job creation and wage growth". Small Business Economics 36 (2011): 15-32. doi: 10.1007/s11187-009-9173-y.

Meyer G. Dale. "The Reinvention of Academic Entrepreneurship.” Journal of Small Business Management49, $\mathrm{n}^{\circ} 1$ (2011): 1-8. doi: 10.1111/j.1540-627X.2010.00311.x.

Santos Correia Susana, Caetano António, and Curral Luís. "Psychosocial aspects of entrepreneurial potential." Journal of Small Business \& Entrepreneurship, 26(6) (2013): 661-685. doi: 10.1080/08276331.2014.892313.

Shane Scott, Locke Edwin A, and Collins Christopher J. "Entrepreneurial motivation."

Human Resources Management Review 13, no 2 (2003): 257-279. doi: 10.1016/ S1053-4822(03)00017-2.

Shane Scott, and Venkataraman Sankaran. "The promise of entrepreneurship as a field of research." Academy of Management Review 25 (2000): 217-226. doi: $10.2307 / 259271$.

Shook Christopher L, Priem Richard L, and McGee Jeffrey E. "Venture creation and the enterprising individual: A review and synthesis." Journal of Management 29 (2003): 379-399. doi: 10.1016/S0149-2063(03)00016-3. 
Siegel Donald S, and Wright Mike. "Academic entrepreneurship: Time for a rethink?" British Journal of Management 26, $\mathrm{n}^{\circ} 4$ (2015): 582-595. doi: 10.1111/14678551.12116.

Villa Sanchez, Aurelio, and Manuel Poblete Ruiz, eds. Competence-based learning, A proposal for the assessment of generic competences. Bilbao: Deusto University Press, 2008.

Wall Glenda P, and Welsch Carsten P. "Employability in Europe: Enhancing Post Graduate Complementary Skills Training." In HEA STEM Learning \& Teaching Conference, Birmnigham, UK, 2013.

Wright Mike, Birley Sue, and Mosey Simon. "Entrepreneurship and university technology transfer." Journal of Technology Transfer, 29(3-4) (2004): 235-246. doi: 10.1023/B:JOTT.0000034121.02507.f3.

\section{About the Author}

SABINA HODZIC (sabina.hodzic@gmail.com) earned her PhD degree (2015) in Psychology of Human Resources from University of Valencia, Spain, and University Paris Descartes, France, where she worked on training in emotional competences for unemployed adults. She is currently a post-doc research fellow at the University Paris Descartes (Laboratoire Adaptations Travail - Individu). Her research is centred on emotional intelligence, well-being, stress, employability and entrepreneurship. She co-authored several articles in high impact factor journals and presented papers at several international conferences. Sabina collaborated with the Tuning Academy in 2014 as a visiting researcher. 


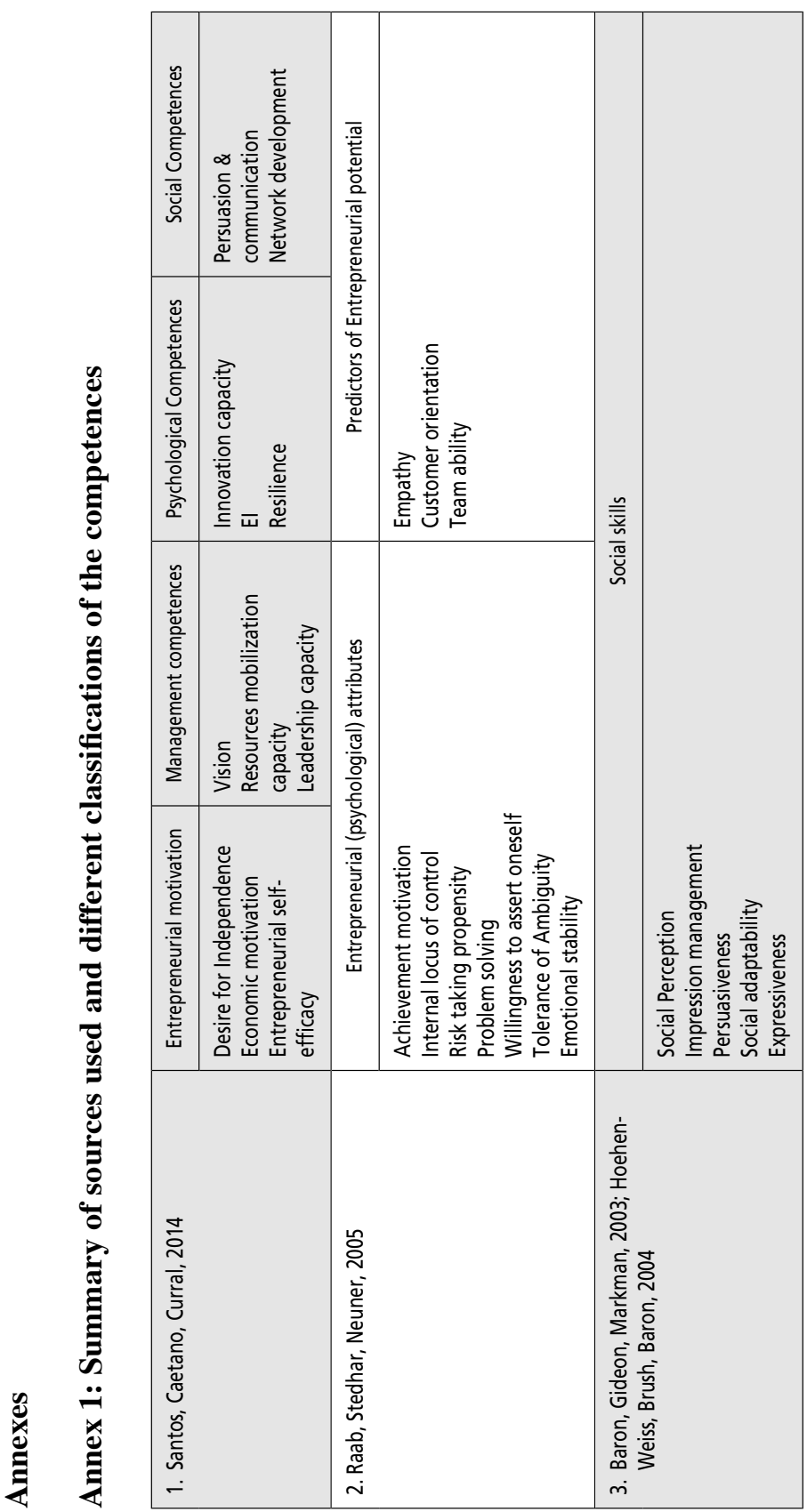

Tuning Journal for Higher Education 


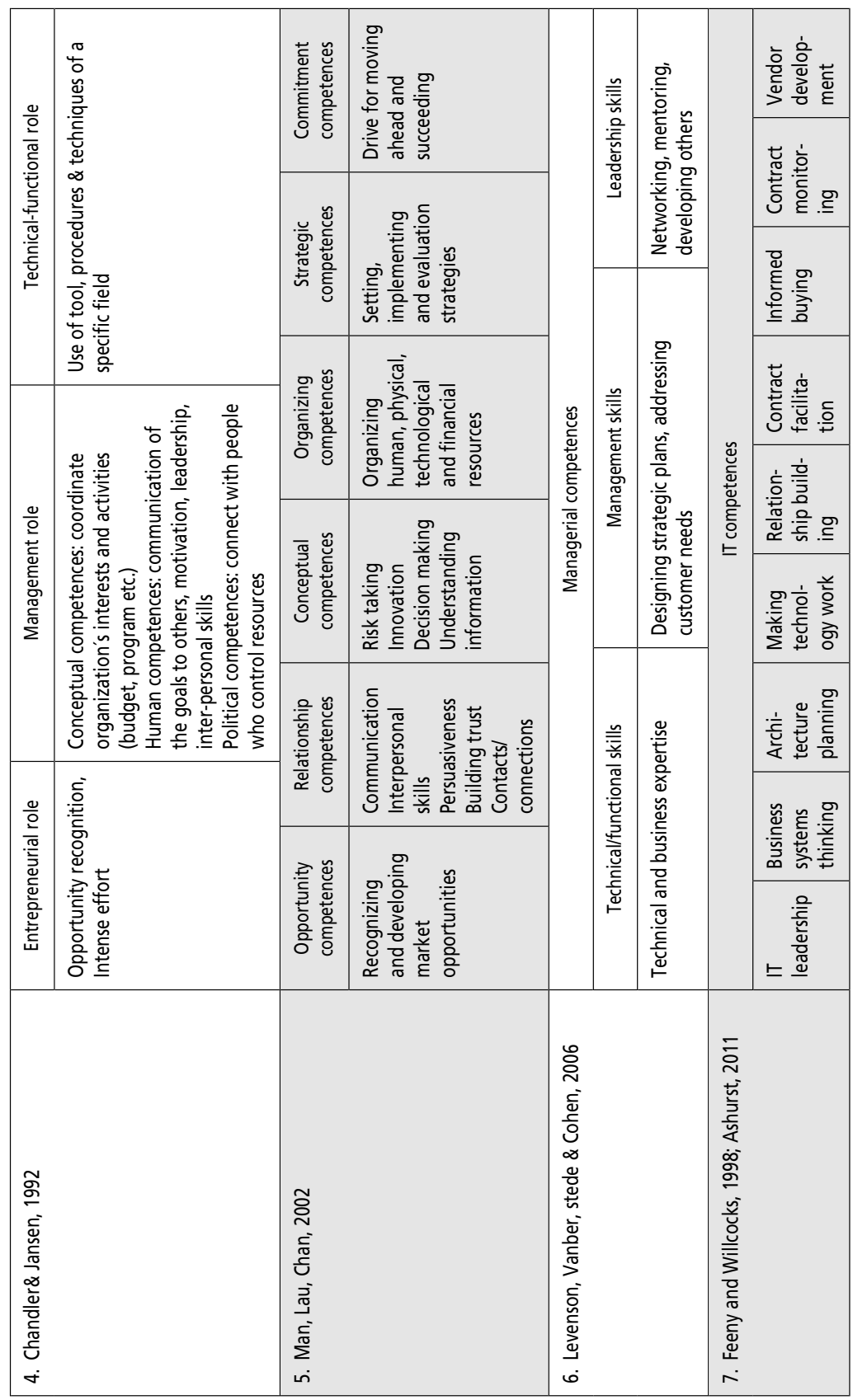




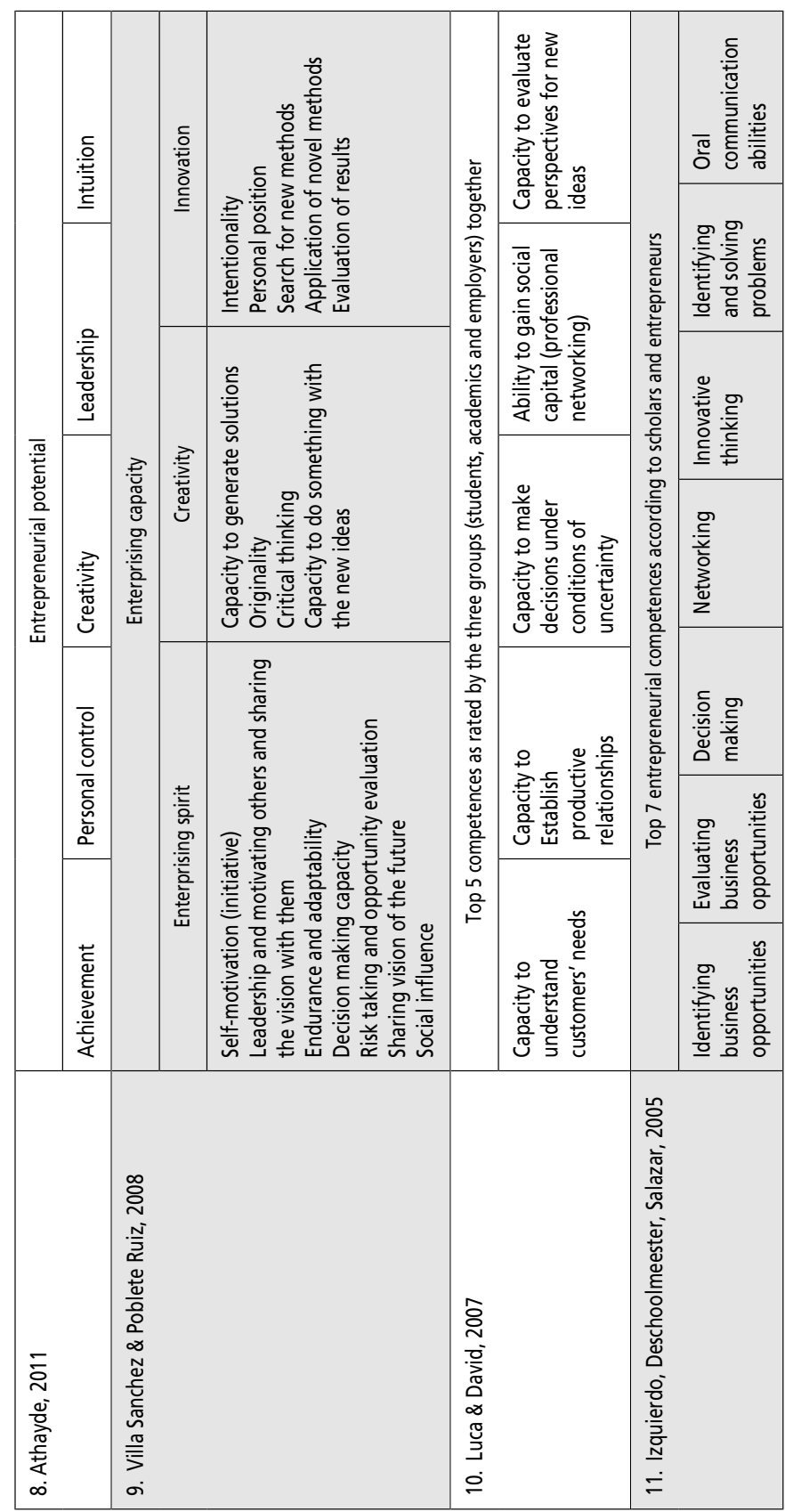

Tuning Journal for Higher Education 


\begin{tabular}{|c|c|}
\hline \multirow{8}{*}{ 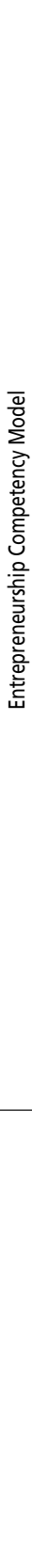 } & 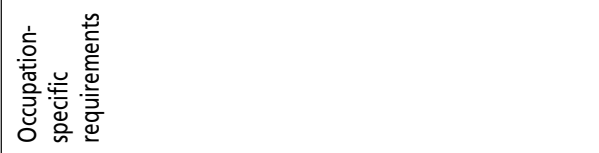 \\
\hline & 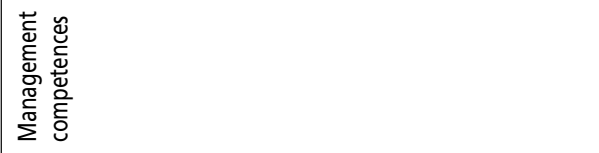 \\
\hline & 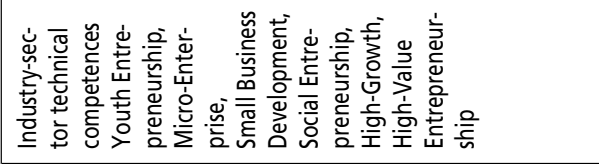 \\
\hline & 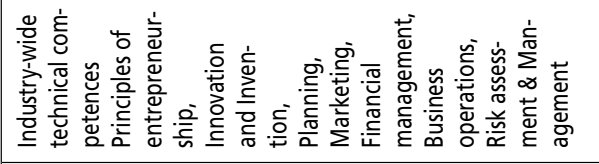 \\
\hline & 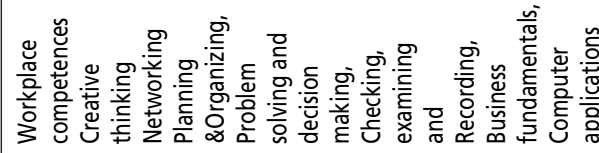 \\
\hline & 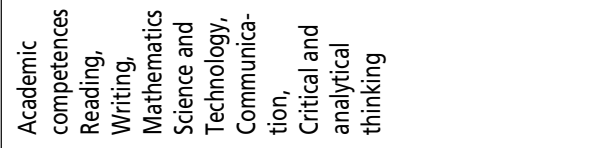 \\
\hline & 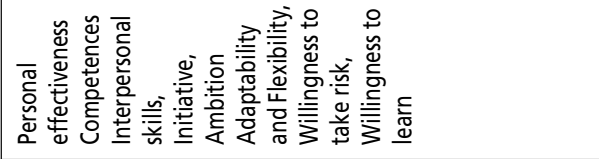 \\
\hline & 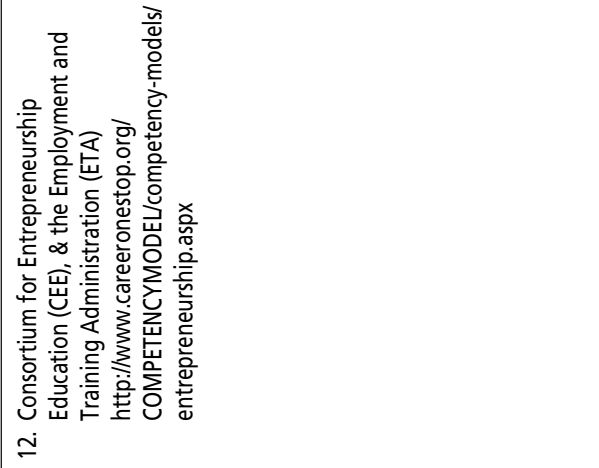 \\
\hline
\end{tabular}




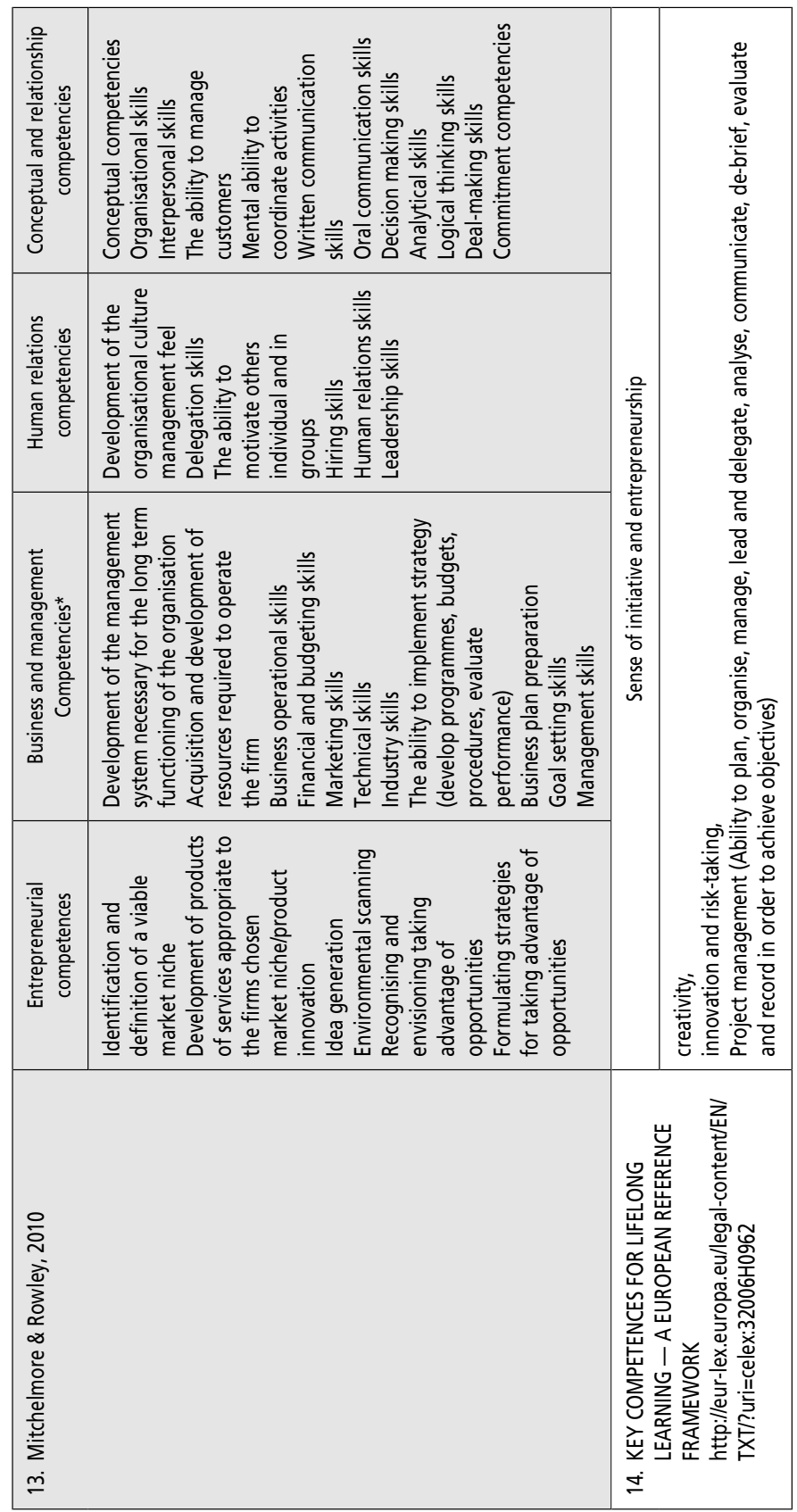




\begin{tabular}{|c|c|}
\hline 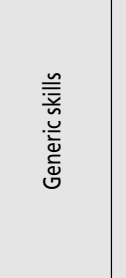 & 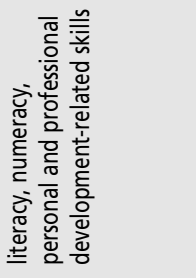 \\
\hline 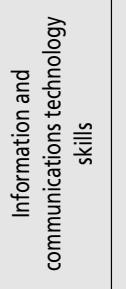 & 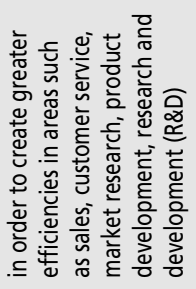 \\
\hline 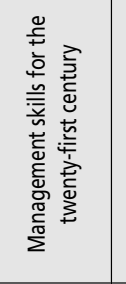 & 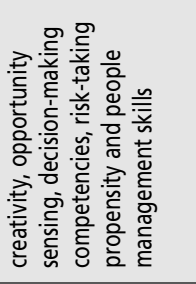 \\
\hline 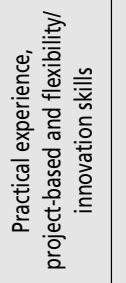 & 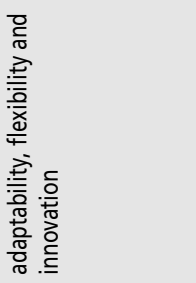 \\
\hline 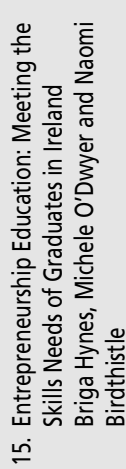 & 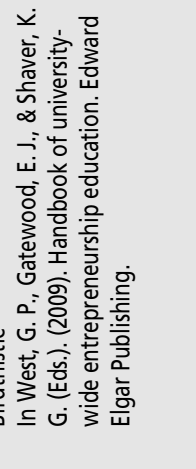 \\
\hline
\end{tabular}




\section{Annex 2. The informed consent form}

\section{CONSENTIMIENTO INFORMADO}

Los investigadores de Deusto International Tuning Academy (DITA) están realizando una investigación sobre competencias emprendedoras de los estudiantes del tercer ciclo de la Universidad de Deusto.

El objetivo de este estudio es identificar las competencias emprendedoras que deben ser incluidas en los programas de estudio de tercer ciclo para que los estudiantes puedan iniciar su propio negocio/empresa/proyecto en sus respectivos campos después de terminar sus estudios de doctorado.

Con el fin de obtener datos para la investigación solicitamos su colaboración, participando en una breve entrevista y evaluando la importancia de cada una de las competencias presentadas.

La información que se obtenga será utilizada con carácter confidencial y de uso exclusivo para fines científicos, respetando el anonimato de los participantes.

El abajo firmante confirma que ha leído y comprendido la información sobre la investigación y que entiende que su participación es voluntaria. Además, es libre para retirarse de la investigación en cualquier momento, sin necesidad de previa justificación. 


\section{Annex 3. The list of entrepreneurial competencies}

1. Have vision and share it with others

2. Recognition and identification of market opportunities or a viable market niche

3. Evaluation and development of market opportunities

4. Understanding market dynamics in a particular field

5. Identification and definition of a viable market niche

6. Development of products or services appropriate to the firms chosen market niche / product innovation

7. Setting, implementing and evaluating strategies

8. Resource mobilization capacity

9. Negotiation and deal making skills

10. Coordinate interests and activities (Budget, program etc.)

11. Customer orientation/ Capacity to understand customers' needs

12. Leadership capacity/ Mentoring, developing others/ Delegation skills

13. Decision making

14. Understanding information

15. Understanding, analyzing and solving problems

16. Organizing human, physical, technological and financial resources

17. Business ethics

18. Willingness to assert oneself/ Resilience/ Intense effort/ Commitment / Endurance and adaptability

19. Emotional stability / Emotional intelligence

20. Creativity

21. Innovation

22. Risk taking propensity

23. Social perception

24. Impression management

25. Persuasivness

26. Social adaptability

27. Expresiveness

28. Written and oral communications skills

29. Network development

30. Interpersonal skills

31. Building trust

32. Ability to gain social capital/ Establish productive relationships

33. Team work

34. Use of tool, procedures \& techniques of a specific field

35. Technical and business expertise/ Business operational skills

36. Financial and budgeting skills

37. Development of management system

38. Marketing skills

39. Business plan preparation

40. IT competences 


\title{
Annex 4. The final version of the interview with the competences questionnaire
}

\author{
Entrevista inicial:
}

\section{A cumplimentar por el entrevistador:}

Fecha

Entrevistador

\section{DATOS PERSONALES}

APELLIDOS

NOMBRE

\section{PREGUNTAS}

1. ¿Qué edad tiene?

2. ¿Nivel de estudios? (años de estudios/título)

3. ¿Qué negocio/empresa/proyecto tiene?

4. ¿Cuál es el sector de su negocio?

5. ¿Por qué ha empezado con este negocio/proyecto/empresa?

6. ¿En qué fase se encuentra actualmente el negocio?

7. ¿Cuándo fue formado?

8. ¿Cuantas personas participan en el negocio/proyecto/empresa?

9. ¿Qué rol tiene Ud. en la empresa?

10. ¿Ha trabajado antes en alguna otra empresa y en cuál? ¿Cuál fue su rol en esa empresa?

11. ¿Qué fue la parte más difícil para empezar y desarrollar el proyecto/ negocio? 
12. ¿Qué le ha ayudado más para empezar? (Qué factor es necesario para empezar con el negocio) ¿Algo en Ud. mismo que le ayudado?

13. ¿Qué factor es necesario para tener éxito y seguir a pesar de los obstáculos?

En continuación se presenta una serie de competencias emprendedoras que se consideran importantes para emprender. Por favor, indique la importancia de cada una de las competencias presentadas eligiendo de 1 (nada importante) a 5 (muy importante).

\begin{tabular}{|c|c|c|c|c|}
\hline 1 & 2 & 3 & 4 & 5 \\
\hline $\begin{array}{c}\text { NADA } \\
\text { IMPORTANTE }\end{array}$ & $\begin{array}{c}\text { ALGO } \\
\text { IMPORTANTE }\end{array}$ & NO SÉ & $\begin{array}{c}\text { BASTANTE } \\
\text { IMPORTANTE }\end{array}$ & $\begin{array}{c}\text { MUY } \\
\text { IMPORTANTE }\end{array}$ \\
\hline
\end{tabular}

\begin{tabular}{|c|c|c|c|c|c|}
\hline \multicolumn{6}{|l|}{ Competencias emprendedoras/Competencias de gestión } \\
\hline 41. Tener visión y compartirla con los demás & 1 & 2 & 3 & 4 & 5 \\
\hline $\begin{array}{l}\text { 42. Reconocimiento e identificación de oportunidades del } \\
\text { mercado }\end{array}$ & 1 & 2 & 3 & 4 & 5 \\
\hline $\begin{array}{l}\text { 43. Evaluación de oportunidades y desarrollo de } \\
\text { oportunidades del mercado }\end{array}$ & 1 & 2 & 3 & 4 & 5 \\
\hline $\begin{array}{l}\text { 44. La comprensión de la dinámica del mercado en un } \\
\text { determinado campo }\end{array}$ & 1 & 2 & 3 & 4 & 5 \\
\hline 45. Identificación y definición de un nicho de mercado viable & 1 & 2 & 3 & 4 & 5 \\
\hline $\begin{array}{l}\text { 46. Desarrollo de productos o servicios adecuados al nicho } \\
\text { de mercado elegido / innovación de productos }\end{array}$ & 1 & 2 & 3 & 4 & 5 \\
\hline $\begin{array}{l}\text { 47. Establecimiento, implementación y evaluación de } \\
\text { estrategias }\end{array}$ & 1 & 2 & 3 & 4 & 5 \\
\hline 48. Capacidad para movilizar los recursos & 1 & 2 & 3 & 4 & 5 \\
\hline 49. Negociación y habilidad para llegar a acuerdos & 1 & 2 & 3 & 4 & 5 \\
\hline $\begin{array}{l}\text { 50. Coordinar intereses y actividades (presupuesto, } \\
\text { programa, etc.) }\end{array}$ & 1 & 2 & 3 & 4 & 5 \\
\hline $\begin{array}{l}\text { 51. Orientación al cliente / Capacidad para comprender las } \\
\text { necesidades de los clientes }\end{array}$ & 1 & 2 & 3 & 4 & 5 \\
\hline $\begin{array}{l}\text { 52. Capacidad de Liderazgo / Guiar, orientar, desarrollar los } \\
\text { demás / habilidades de delegación }\end{array}$ & 1 & 2 & 3 & 4 & 5 \\
\hline
\end{tabular}




\section{Competencias emprendedoras/Competencias de gestión}

53. La toma de decisiones (incluso bajo condiciones de incertidumbre)

54. Comprensión de la información

55. Comprensión y resolución de problemas

56. Organización de los recursos humanos, físicos, tecnológicos y financieros

57. La ética empresarial

\begin{tabular}{|l|l|l|l|l|}
1 & 2 & 3 & 4 & 5 \\
1 & 2 & 3 & 4 & 5 \\
1 & 2 & 3 & 4 & 5 \\
\hline 1 & 2 & 3 & 4 & 5 \\
1 & 2 & 3 & 4 & 5 \\
\hline
\end{tabular}

\section{Competencias psicológicas}

58. La voluntad para asertividad personal / Resiliencia / Intenso esfuerzo / Compromiso / Resistencia y adaptabilidad

59. Estabilidad emocional/Inteligencia emocional

60. Creatividad

(Capacidad para generar soluciones, originalidad, pensamiento crítico, capacidad de hacer algo con ideas nuevas)

61. Innovación

(Indicadores: intencionalidad, actitud y posición personal, búsqueda y aplicación de nuevos métodos, evaluación de los resultados)

62. Propensión para tomar riesgos

\section{Competencias sociales}

63. Percepción social

64. Saber dejar buena impresión

65. Persuasión

66. Adaptabilidad social

67. Expresividad / Comunicación oral

68. Habilidades de comunicación escrita

69. Desarrollo de las redes

70. Habilidades interpersonales 


\begin{tabular}{|l|c|c|c|c|c|}
\hline \multicolumn{5}{|c|}{ Competencias sociales } \\
\hline 71. Creación de confianza & 1 & 2 & 3 & 4 & 5 \\
\hline $\begin{array}{l}\text { 72. Capacidad para obtener el capital social / Establecer } \\
\text { relaciones productivas }\end{array}$ & 1 & 2 & 3 & 4 & 5 \\
\hline 73. Trabajo en equipo & 1 & 2 & 3 & 4 & 5 \\
\hline
\end{tabular}

\begin{tabular}{|c|c|c|c|c|c|}
\hline \multicolumn{6}{|l|}{ Competencias técnicas } \\
\hline $\begin{array}{l}\text { 74. Uso de herramientas, procedimientos y técnicas de un } \\
\text { campo específico }\end{array}$ & 1 & 2 & 3 & 4 & 5 \\
\hline $\begin{array}{l}\text { 75. Conocimiento técnico y de negocios/ Habilidades } \\
\text { operativas de negocio }\end{array}$ & 1 & 2 & 3 & 4 & 5 \\
\hline 76. Habilidades financieras y de hacer presupuestos & 1 & 2 & 3 & 4 & 5 \\
\hline 77. Desarrollo del sistema de gestión & 1 & 2 & 3 & 4 & 5 \\
\hline 78. Habilidades de marketing & 1 & 2 & 3 & 4 & 5 \\
\hline 79. Preparación del "business plan" & 1 & 2 & 3 & 4 & 5 \\
\hline 80. Competencias de IT & 1 & 2 & 3 & 4 & 5 \\
\hline
\end{tabular}

14. ¿Hay alguna competencia de esa lista que destacarías en especial como extremadamente importante o útil o extremadamente inútil? ¿Por qué?

15. ¿Hay algo más que quiere destacar como necesario/importante/ imprescindible para emprender? ¿Por qué?

16. ¿Hay algo de los estudios que finalizaste que te ha ayudado en especial para emprender?

17. ¿Qué incluirías tú al programa de tus estudios para ayudar a los futuros emprendedores? 


\section{Annex 5. Definitions of the competences}

\begin{tabular}{|c|c|}
\hline \multicolumn{2}{|c|}{ Competencias emprendedoras/Competencias de gestión } \\
\hline $\begin{array}{l}\text { 1. Tener visión y compartirla con los } \\
\text { demás }\end{array}$ & $\begin{array}{l}\text { Tener meta idealizada que se } \\
\text { quiere conseguir en el futuro o una } \\
\text { imagen ideal y única del futuro que } \\
\text { sirve como guía para las acciones } \\
\text { emprendedoras. Saber compartir y } \\
\text { comunicar la visión de futuro a los } \\
\text { demás. }\end{array}$ \\
\hline $\begin{array}{l}\text { 2. Reconocimiento y evaluación } \\
\text { de oportunidades / Reconocer } \\
\text { y desarrollar oportunidades del } \\
\text { mercado }\end{array}$ & $\begin{array}{l}\text { Capacidad de reconocer, } \\
\text { evaluar, concebir y desarrollar } \\
\text { las oportunidades del mercado, } \\
\text { considerando los intereses personales } \\
\text { y posibles consecuencias sociales. }\end{array}$ \\
\hline $\begin{array}{l}\text { 3. Identificación y definición de un } \\
\text { nicho de mercado viable }\end{array}$ & $\begin{array}{l}\text { Capacidad de realizar la exploración } \\
\text { del entorno para obtener información } \\
\text { de marketing, de identificar una } \\
\text { base de clientes, de definir un nicho } \\
\text { de mercado, de hacer análisis de } \\
\text { mercado y de los clientes. }\end{array}$ \\
\hline $\begin{array}{l}\text { 4. Desarrollo de productos o servicios } \\
\text { adecuados al nicho de mercado } \\
\text { elegido / innovación de productos }\end{array}$ & $\begin{array}{l}\text { Implementar varios métodos para } \\
\text { generar un producto/servicio/idea. }\end{array}$ \\
\hline $\begin{array}{l}\text { 5. Establecimiento, implementación y } \\
\text { evaluación de estrategias }\end{array}$ & $\begin{array}{l}\text { Capacidad de determinar la dirección } \\
\text { de una organización / empresa } \\
\text { y el establecer la estrategia para } \\
\text { lograr esa dirección. Preparar } \\
\text { planes completos: plan financiero, } \\
\text { plan contable, plan legal, plan de } \\
\text { gestión, plan de producción, y el plan } \\
\text { operativo. }\end{array}$ \\
\hline $\begin{array}{l}\text { 6. Capacidad para evaluar las } \\
\text { perspectivas para nuevas ideas }\end{array}$ & \\
\hline $\begin{array}{l}\text { 7. Capacidad para movilizar los } \\
\text { recursos }\end{array}$ & $\begin{array}{l}\text { Capacidad de organizar los recursos } \\
\text { financieros y materiales para } \\
\text { gestionar una empresa con el objetivo } \\
\text { de proporcionar la empresa con } \\
\text { flexibilidad estratégica y facilitar su } \\
\text { adaptación a entornos complejos. }\end{array}$ \\
\hline
\end{tabular}


Competencias emprendedoras/Competencias de gestión

8. Coordinar intereses y actividades (presupuesto, programa, etc.)

9. Orientación al cliente / Capacidad para comprender las necesidades de los clientes
Capacidad de coordinar todos los intereses y actividades de la organización.

Capacidad de entender y orientarse hacia las necesidades del cliente. Capacidad de concentrar el pensamiento operacional y la acción en el cliente (en las necesidades, deseos, expectativas y problemas del cliente).

10. Capacidad de Liderazgo / Guiar, orientar, desarrollar los demás / habilidades de delegación

Capacidad de influir en los demás, gestionar recursos con el fin de enfatizar los comportamientos de búsqueda de oportunidades y de ventajas. Capacidad de entender, motivar, delegar los demás.

11. La toma de decisiones (incluso bajo condiciones de incertidumbre) los intereses personales y posibles consecuencias sociales. En casos de
Saber tomar decisiones considerando situaciones muy complejas, buscar ayuda para confrontar problemas. Evaluar numerosas soluciones potenciales, tomar decisiones difíciles, incluso en ausencia de datos sólidos o en situaciones ambiguas, observar los resultados de la implementación de la solución, evaluar la necesidad de enfoques alternativos e identificar las lecciones aprendidas.

12. Comprensión de la información

Capacidad de entender la información compleja.

13. Comprensión y resolución de problemas

La aplicación de habilidades de pensamiento crítico para resolver problemas mediante la generación, evaluación e implementación de soluciones.

14. Organización de los recursos humanos, físicos, tecnológicos y financieros

\section{Capacidad de organizar diferentes} recursos internos y externos (humanos, físicos, financieros y tecnológicos (team-building, gestionar los empleados, formación y control. 
Annex 6. The ranking of the importance of entrepreneurial competences made by entrepreneurs - in order of item list

\begin{tabular}{|c|c|c|c|c|c|}
\hline Competence & $\mathrm{N}$ & Min & Max & Mean & SD \\
\hline 1. Have vision and share it with others & 17 & 4 & 5 & 4.47 & .51 \\
\hline $\begin{array}{l}\text { 2. Recognition and identification of } \\
\text { market opportunities or a viable } \\
\text { market niche }\end{array}$ & 17 & 4 & 5 & 4.47 & .51 \\
\hline $\begin{array}{l}\text { 3. Evaluation and development of } \\
\text { market opportunities }\end{array}$ & 17 & 3 & 5 & 4.53 & .62 \\
\hline $\begin{array}{l}\text { 4. Understanding market dynamics in a } \\
\text { particular field }\end{array}$ & 17 & 2 & 5 & 4.12 & .69 \\
\hline $\begin{array}{l}\text { 5. Identification and definition of a } \\
\text { viable market niche }\end{array}$ & 17 & 4 & 5 & 4.41 & .51 \\
\hline $\begin{array}{l}\text { 6. Development of products or services } \\
\text { appropriate to the firms chosen } \\
\text { market niche / product innovation }\end{array}$ & 17 & 3 & 5 & 4.35 & .61 \\
\hline $\begin{array}{l}\text { 7. Setting, implementing and evaluating } \\
\text { strategies }\end{array}$ & 17 & 2 & 5 & 3.60 & 1.06 \\
\hline 8. Resource mobilization capacity & 17 & 2 & 5 & 3.94 & 1.08 \\
\hline 9. Negotiation and deal making skills & 17 & 2 & 5 & 4.47 & .79 \\
\hline $\begin{array}{l}\text { 10. Coordinate interests and activities } \\
\text { (Budget, program etc.) }\end{array}$ & 17 & 2 & 5 & 4.00 & .79 \\
\hline $\begin{array}{l}\text { 11. Customer orientation/ Capacity to } \\
\text { understand customers' needs }\end{array}$ & 17 & 4 & 5 & 4.82 & .39 \\
\hline $\begin{array}{l}\text { 12. Leadership capacity/ Mentoring, } \\
\text { developing others/ Delegation skills }\end{array}$ & 17 & 3 & 5 & 4.30 & .69 \\
\hline 13. Decision making & 17 & 4 & 5 & 4.53 & .51 \\
\hline 14. Understanding information & 17 & 2 & 5 & 3.76 & 1.20 \\
\hline $\begin{array}{l}\text { 15. Understanding, analyzing and solving } \\
\text { problems }\end{array}$ & 17 & 4 & 5 & 4.53 & .51 \\
\hline $\begin{array}{l}\text { 16. Organizing human, physical, } \\
\text { technological and financial resources }\end{array}$ & 17 & 2 & 5 & 4.00 & .86 \\
\hline 17. Business ethics & 17 & 2 & 5 & 3.60 & 1.12 \\
\hline
\end{tabular}




\begin{tabular}{|c|c|c|c|c|c|}
\hline Competence & $\mathrm{N}$ & Min & Max & Mean & SD \\
\hline $\begin{array}{l}\text { 18. Willingness to assert oneself/ } \\
\text { Resilience/ Intense effort/ } \\
\text { Commitment / Endurance and } \\
\text { adaptability }\end{array}$ & 17 & 3 & 5 & 4.53 & .62 \\
\hline $\begin{array}{l}\text { 19. Emotional stability / Emotional } \\
\text { intelligence }\end{array}$ & 17 & 2 & 5 & 4.30 & .85 \\
\hline 20. Creativity & 17 & 3 & 5 & 4.47 & .62 \\
\hline 21. Innovation & 17 & 2 & 5 & 4.00 & .94 \\
\hline 22. Risk taking propensity & 17 & 2 & 5 & 3.47 & .94 \\
\hline 23. Social perception & 17 & 1 & 5 & 3.41 & 1.12 \\
\hline 24. Impression management & 17 & 2 & 5 & 4.00 & .94 \\
\hline 25. Persuasivness & 17 & 2 & 5 & 4.00 & .94 \\
\hline 26. Social adaptability & 17 & 2 & 5 & 3.60 & 1.06 \\
\hline 27. Expresiveness & 17 & 2 & 5 & 4.18 & 1.01 \\
\hline 28. Written and oral communications skills & 17 & 2 & 5 & 4.06 & .83 \\
\hline 29. Network development & 17 & 2 & 5 & 4.12 & .78 \\
\hline 30. Interpersonal skills & 17 & 4 & 5 & 4.50 & .51 \\
\hline 31. Building trust & 17 & 3 & 5 & 4.60 & .62 \\
\hline $\begin{array}{l}\text { 32. Ability to gain social capital/ Establish } \\
\text { productive relationships }\end{array}$ & 17 & 2 & 5 & 4.00 & .87 \\
\hline 33. Team work & 17 & 3 & 5 & 4.47 & .72 \\
\hline $\begin{array}{l}\text { 34. Use of tool, procedures \& techniques } \\
\text { of a specific field }\end{array}$ & 17 & 2 & 5 & 3.60 & .94 \\
\hline $\begin{array}{l}\text { 35. Technical and business expertise/ } \\
\text { Business operational skills }\end{array}$ & 17 & 2 & 5 & 3.76 & .97 \\
\hline 36. Financial and budgeting skills & 17 & 1 & 5 & 3.24 & 1.25 \\
\hline 37. Development of management system & 17 & 1 & 5 & 2.82 & 1.01 \\
\hline 38. Marketing skills & 17 & 2 & 5 & 4.06 & .75 \\
\hline 39. Business plan preparation & 17 & 2 & 5 & 3.41 & .87 \\
\hline 40. IT competences & 17 & 2 & 5 & 3.53 & 1.01 \\
\hline
\end{tabular}




\title{
Increasing PhD students' employability by focusing on the academic entrepreneurship. The analysis of the entrepreneurial competences
}

\author{
Sabina Hodzic
}

\section{Copyright}

Copyright for this article is retained by the Publisher. It is an Open Access material that is free for download, distribution, and or reuse in any medium only for non-commercial purposes; provided any applicable legislation is respected, the original work is properly cited, and any changes to the original are clearly indicated. 